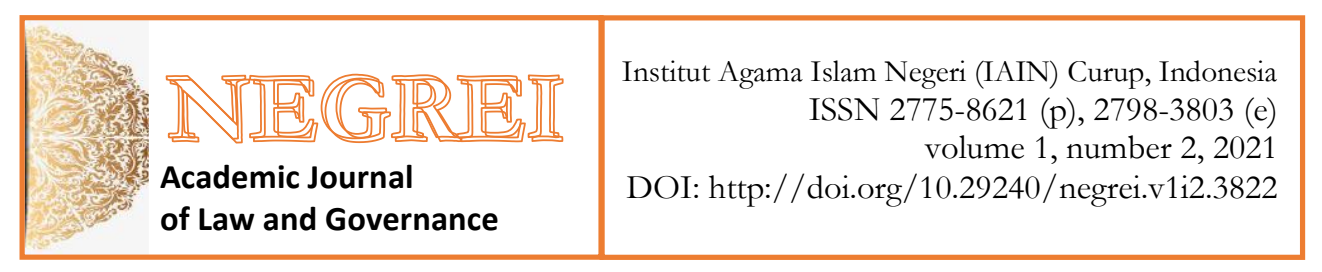

\title{
Modelling Australian Transaction Reports and Analysis Centre (AUSTRAC) for Indonesia in Order to Combat Financial Crime
}

\section{Beny Saputra}

University Of Szeged, Hungary

benysaputraszeged@gmail.com

\begin{abstract}
Financial technology (Fin'Tech) rapidly expanding in Indonesia, fund manager around the world eager to invest and diversify their portofolio in this new business strategy, this is due to the fact that Indonesia is the largest economy in the South East Asian (ASEAN) region as well as the 4th most populated country in the planet. As a result this make the market for financial technology in Indonesia has enormous potential in the future. However, because financial crime is a threat, Indonesia must enchancing their Anti Money laundry (AML) laws for being more practical and adaptable to the current situation. This paper will do doctrinal legal research to analyze effectiveness current law applicable to fight againts money launderer in Indonesia and comparative law system with modelling AUSTRAC from the Australia which have similar issue with Indonesia. In this respect, data suggest Indonesia in condition almost rechtvaccum for financial tehcnology law and AUSTRAC system in Australia most likely sufficient to implement in Indonesia in order combat money launderer.
\end{abstract}

Keywords: Financial Technology, Financial Crime, Anti- Money Laudry (AML), Indonesia. 
NEGREI : Academic Journal of Law and Govenance,

Volume 1, Number 2, 2021

\section{Introduction}

Indonesia as the 4th most populated country in the planet becoming one of the world's fastest growing cosumer market. Despite of Covid-19 crisis affected economy in 2020, Indonesia growth steady over the last decade in 5\% with GDP reached over $\$ 1,1$ trilion in 2019 .

With the population approximatelly 270 millions of people with half of the populations below 30 years old, the market potential for the demand of the consumer goods, targeted education and training, and innovative knowledge creative based service and technology. The demand of the internet usage also growing significantly, the number of smartphone users in Indonesia is estimated to reach 199.2 million users in 2021. Currently, Indonesia is the fourth-largest smartphone market worldwide after China, India and the United States (statista.com, 2021). This is enabling government, business and consumer to take advantage of the new digital services.

The strong growth of emerging economy with huge potential increase the financial business in Indonesia particulary financial technology or popular well known as FINTECH. The booming of Indonesia economy has carved a clear path to leverage financial technology start up. Currently, more than 150 found in Indonesia, a growth of $78 \%$ since 2015. As per may November 2021, there 300 FinTech in the country with investment over $\$ 329$ millions. This amount put Indonesia dominated the FinTEch leaderboard in Southeast Asia.

Financial Technology (Fin'Tech) continues to change habits with its easy, fast, and competitively priced solutions. With FinTech, we witness how technologies that facilitate human life have grown and complied with. FinTech has reached billions of customers with digital banking, e-wallets, and digital payment services. The solutions provided by financial technology companies based on customer experience have the most significant share in this success.

If we look at the coming years, the FinTech customer mass's growth with the services types of financial technology companies is not far away. Although some financial technology companies provide similar services in traditional banking, it is a great mistake to think that Fin'Tech and traditional banks are rivals. FinTech should not forget that it can achieve great growth with supportive solutions to the banking sector. In recent years, we have been witnessing win-win-focused agreements between banks and financial technology companies frequently. 


\section{Beny Saputra \\ Modelling Australian Transaction Reports and Analysis Centre (AUSTRAC) for Indonesia in Order to Combat Financial Crime}

While following the growth of FinTech, we also face some important financial crime risks. As a result of the abuse of fast financial services provided by FinTech, financial crimes have started to be committed. Committing crimes through fast and easy solutions provided by financial technology companies made it compulsory for companies to take some precautions.

financial crimes such as money laundering, terrorist financing, corruption, and bribery are example of the financial crime can commited by financial technology. Those illegal activity obviously will through legal financial system or do money laundry. Money laundry is a illegal process of making large amount of money generated by criminal activity, appears to have come from a legitimate process. The purpose of the money laundry is to claim the money is a genuine and legal.

for example, The Financial Reports and analysis centre (PPATK) in Indonesia reported a finding on December 2019 number of money laundring schemes by regional heads through the casino. The amount was significant up to USD 50 billion sum up from split of foreign exchange into casino's account in the Highland, Genting, Malaysia, Casino. This report was shocking since it was undetecable by the traditional bank system and it was done through the digital banking system and suspected involved a senior banker and member of regional representative council (DPD) or Indonesian Senator.

The Financial Reports and Analysis Cente also reported during 2014 and 2015 ago terrorism actor in Indonesia received fund from the overseas amount up to USD 763,000. The fund transferred through many ways from traditional way brought the cash through indonesian immigrant worker in Malaysia, Singapore and Middle East. By using financial system or bank system according to the PPATK report the money directed to Indonesia from various countries with advance Bank system such us Singapore, Hong Kong (PRT) and Malaysia.

On July 2019 Indonesian Police Department announced arrested Para Wijayanto, he was suspected as the Leader of Jama'ah Islamiyyah (JI), this organization responsibe for Bali bombings 2002. Police was shock that Para Wijayanto utilize Banking Digital system and finance the terrorism activity from legitimate business activity like oil palm plantation. However, the bank system didn't detect the transaction activity of the terrorist since they were using digital banking system and according to the bank it was legal and legitimate. 
NEGREI : Academic Journal of Law and Govenance,

Volume 1, Number 2, 2021

Corruption, Terrorism, Human Trafficking, Drug Dealer activity obviously will involve financial system into it. Conventionally, Corruptor, Drug dealer, and Human trafficking organization will do money laundy. In practice they will try to hide source of the fund which is from criminal activity obtained so its looks like obtained from legal business activity. Money laundry is a illegal process of making large amount of money generated by criminal activity, such us corruption, terrorism funding, human trafficking, drug trafficking, appears to have come from a legitimate process. The purpose of the money laundry is to claim the money is a genuine and to confuse source of the fund. Money laundry consider as serious financial crime and can be involving white collar people inside the system.

Money Laundering according to the Financial action Task Force (FAFT) its a The goal of a large number of criminal acts is to generate a profit for the individual or group that carries out the act. Money laundering is the processing of these criminal proceeds to disguise their illegal origin. This process is of critical importance, as it enables the criminal to enjoy these profits without jeopardising their source. Illegal arms sales, smuggling, and the activities of organised crime, including for example drug trafficking and prostitution rings, can generate huge amounts of proceeds. Embezzlement, insider trading, bribery and computer fraud schemes can also produce large profits and create the incentive to "legitimise" the ill-gotten gains through money laundering. When a criminal activity generates substantial profits, the individual or group involved must find a way to control the funds without attracting attention to the underlying activity or the persons involved. Criminals do this by disguising the sources, changing the form, or moving the funds to a place where they are less likely to attract attention.(FAFT, 2021)

In response to mounting concern over money laundering, the Financial Action Task Force on money laundering (FATF) was established by the G-7 Summit in Paris in 1989 to develop a co-ordinated international response. One of the first tasks of the FATF was to develop Recommendations, 40 in all, which set out the measures national governments should take to implement effective anti-money laundering programmes.

the United Nations Office on Drugs and Crime (UNODC) conducted a study to determine the magnitude of illicit funds generated by drug trafficking and organised crimes and to investigate to what extent these funds are 


\section{Beny Saputra \\ Modelling Australian Transaction Reports and Analysis Centre (AUSTRAC) for Indonesia in Order to Combat Financial Crime}

laundered. The report estimates that in 2009, criminal proceeds amounted to $3.6 \%$ of global GDP, with $2.7 \%$ (or USD 1.6 trillion) being laundered. (UNODC, 2021)

This falls within the widely quoted estimate by the International Monetary Fund, who stated in 1998 that the aggregate size of money laundering in the world could be somewhere between two and five percent of the world's gross domestic product. Using 1998 statistics, these percentages would indicate that money laundering ranged between USD 590 billion and USD 1.5 trillion. At the time, the lower figure was roughly equivalent to the value of the total output of an economy the size of Spain.

However, the above estimates should be treated with caution. They are intended to give an estimate of the magnitude of money laundering. Due to the illegal nature of the transactions, precise statistics are not available and it is therefore impossible to produce a definitive estimate of the amount of money that is globally laundered every year.

Act againts money launderer was taken serious by the world due to risk of the financial crime will relate to the terrorism, corruption and its also consider as crime cross country. As consideration of the act, countries around the world working together to establish a system and rules to prevention and punishment of the financial crime. On other hand, financial industry which is the front line of the financial system, become more aware about the situation with apply Anti Money Laundry (AML) through the system well knows as Know your customer (KYC) . However, The AML system applied in the bank system excessive and useless reporting, well know as the "crying wolf effect" (Takats, 2011).

The AML system is a crucial shortcoming to address and fix money launderer, the "crying wolf effect" harm the information values of the report that bank and other professionals are obliged to file in order to comply with AML regulations. (Lucia, Giorgio, Donato, Margherita, Feb 2021).

Between 2007 and 2010, AML policies in both the US and in Europe switched from a rulebased reporting system to a risk-based system in which all layers of the system need to respond to money-laundering threats in ways that are proportionate to the risks involved.1 In particular, financial intermediaries and other professionals are required to play an active role in identifying suspicious 
NEGREI : Academic Journal of Law and Govenance,

Volume 1, Number 2, 2021

transactions (Black \& Baldwin, 2010; Dalla Pellegrina \& Masciandaro, 2009). They must exploit their knowledge and other information regarding the financial habits of their customers (the know-your-customer (KYC) approach) to better determine which transactions should be reported as suspicious to the FIU. They must also apply their subjective judgment to assess the actual risk that a transaction is money laundering. In fact, intermediaries and 12 professionals are required to adjust their reporting criteria and, therefore, move up or down their decisional bars (i.e., a type of standard of evidence) when deciding whether to report a transaction to the FIU depending on the actual risk of money laundering (Axelrod, 2017; Lowe, 2017).

Indonesia in other side has traditionally struggled with money laundering threats thanks to a lack of regulation and institutional corruption. However, since the turn of the century, the government has stepped up its efforts to fight financial crime and promote anti-money laundering in Indonesia through legislation. In 2002, those efforts were marked by the introduction of the Pusat Pelaporan dan Analysis Transaksi Keuangan (PPATK), Indonesia's financial intelligence unit, and the passage of legislation specifically targeting money laundering and associated crimes like the financing of terrorism.

Indonesia Anti Money Launderer (AML) system still conservatif and heavy with written regulations and non practical specially for the financial system specially financial technology. Insufficient capability to catch up with the new financial era technology will make Indonesia will have big threat in financial crime and potentially will remove from global financial system. In 2012, the Financial Action Task Force (FATF) put Indonesia on a blacklist of countries at a high risk of money laundering. After working to address its AML deficiencies, Indonesia was removed from that list in 2015 and, in 2018, was granted 'observer' FATF status with a view to achieving full membership status in the future. (FAFT, 2021).

In line with the background above, there two one issue will be decribed in this paper.

1. What rules applicable in Indonesia to prevent money launderer currently?

2. From which country Anti Money Laudering modelling system Indonesia can adopt? 


\section{Beny Saputra \\ Modelling Australian Transaction Reports and Analysis Centre (AUSTRAC) for Indonesia in Order to Combat Financial Crime}

Methodology used by this paper to answer those issue are doctrinal legal research and comparative law method. Doctrinal derived from the latin doctrina that mean to instruct, a lesson, a precept, knowledge or learning. This reseach process is used to identify, analyze and synthesis the content of law and the history (Istvan Harkai, 2021). Argument are derived from authoritative sources, such us existing rules, principles, precedent, and scholarly publications (Van Gestel, 2008). In this paper, doctrinal legal research more likely to analyze current applicable laws, statuta, acts, and rules relate with such issues.

Comparative law method its a method with put together several objects or several elements of one or more objects in order to examine the degrees of similarity so as to be able to draw conclusions from them that the analysis of each of them alone would necessarily have allowed one to draw. (Chevrel, 2012). In the law the only things which are comparable are those which fulfil the same function. (Zweigert-Kötz, 2021). In this paper, we will described Anti Money launderer from few countries. From this comparison we can conclude which model Indonesia can Adopt.

\section{Financial Crime}

\section{Definition and Historical of Financial Crime.}

Financial crime is generally defined as any activity that involves fraudulent or dishonest behavior for the purposes of personal financial gain, although it may also include the illegal conversion of property ownership. Financial crime may be committed by individuals or groups and involve the following activities:

1. Money laundering

2. Terrorism financing

3. Fraud

4. Tax evasion

5. Embezzlement

6. Forgery

7. Counterfeiting

8. Identity theft

Financial crime has been around since the invention of currency. Some would argue its origins begin even further back in history, with the advent of trade. If 
NEGREI : Academic Journal of Law and Govenance,

Volume 1, Number 2, 2021

true, we can imagine the first instances of fraud involved trading wormy fruits, soured wine, or sick livestock. During those times, any exchange that knowingly defrauded the other side of a transaction was, in fact, financial crime. (businessforensic, 2021).

\section{The Earliest Examples of Financial Crime}

Humans began smelting copper roughly 8,000 years ago, and so began The Bronze Age. We can only guess at the instances of ore-swapping that probably occurred. Fast-forward 4,000 years, and we know for sure that financial crime existed during Biblical times. How old are those texts? Scholars suspect the Old Testament / Hebrew stories to be about 4,000 years old, but the oldest hard copy we have found - The Dead Sea Scrolls — is probably half that age.

That's not to say fraud and theft weren't happening in Ancient Egypt, India, or Ancient Central American Civilizations. We know, for instance, that ancient Egyptians had laws and we see depicted punishments. But we don't have a copy of their code of law.

Reading the ancient texts we do have, we find the oldest instances of financial crime manifested as:

1. Dishonest weights and measures meant to defraud trade customers

2. Dishonest money-changing among different nations and tribes (related to our modern currency exchange scams)

3. Exorbitant usury (today we call them interest charges and fees)

4. And plotting to steal someone's inheritance - a forefather of life insurance scams, property inheritance scams, and senior extortion, today.

The Jewish Virtual Library says punishments during these early eras were mostly corporal. Think "an eye for an eye."

1. Public stoning, beatings, and whippings, "slaying," strangulation, and crucifixion were commonplace!

2. Interestingly, human greed was a more powerful drive than fear of, say, losing a hand or an eye or even a violent death in the streets.

We're not exactly sure what brought about the end of The Bronze Age. The History Channel suggests it was a combination of famines and earthquakes. But we know financial crimes continued through the Iron Age and Antiquity. 
Beny Saputra

Modelling Australian Transaction Reports and Analysis Centre (AUSTRAC) for Indonesia in Order to Combat Financial Crime

\section{Financial Crimes in the Graeco-Roman Period}

The Romans took banking out of religious temples and formalized it in distinct buildings. This was the beginning of banking as we know it. And thus began a new era of financial crime, mostly associated with moneylenders profiting from taking in and lending money and centuries of land grabs.

The First Known Case of Insurance Fraud

One of the first known instances of insurance fraud happened around $300 \mathrm{CE}$ when Hegestratos, a Greek Merchant, took out a loan using his ship full of corn as collateral.

1. This sort of loan/insurance policy was called "bottomry," referring to a ship's keel or its bottom.

2. He planned to sink an empty boat, keep the loan, and sell the corn.

3. Ultimately, his plan failed.

4. He drowned, trying to escape the sinking ship, and was caught in the act.

While this is the first recorded instance, we can imagine this sort of fraud was rampant at the time.

After the fall of Rome, banking in the commercial sense was largely abandoned. It didn't revive until the crusades when powerful bankers emerged from the Holy Roman Empire. Remember, the ancient texts saw usury/interest as immoral.

\section{The Return of Banking}

Eventually, commerce expanded. Bills of exchange were needed to avoid the risks associated with transporting large chests of treasure. Though it wasn't until the sixteenth century that banks were commonplace again. So we'll spin the globe 1,300 times and gloss over centuries of burglary, robbery, counterfeiting, and kidnappings for ransom to arrive in the Victorian Era because that's when our modern concept of "white-collar crime" takes root.

\section{Financial Crime in the Information Age}

Of all the eras of human history, none are more complicated than today. Modern financial crimes are happening right now in the forms of:

1. Life insurance fraud

2. Property insurance fraud 
NEGREI : Academic Journal of Law and Govenance,

Volume 1, Number 2, 2021

3. Cargo fraud

4. Embezzlement

5. Illicit loan-sharking

6. Money-laundering

7. Identity theft and benefit theft

8. Senior citizen extortion

Our global economy and the advent of Cryptocurrencies only make these transactions more difficult to track and unravel.

\section{Money Laundry}

\section{Definition and impact}

Money laundering is the illegal process of making large amounts of money generated by a criminal activity, such as drug trafficking or terrorist funding, appear to have come from a legitimate source. The money from the criminal activity is considered dirty, and the process "launders" it to make it look clean.

The money laundering process most commonly occurs in three key stages: placement, layering and integration. Each individual money laundering stage can be extremely complex due to the criminal activity involved. (ST Paul Chamber, 2021)

\section{Placement}

The first stage of money laundering is known as 'placement', whereby 'dirty' money is placed into the legal, financial systems. After getting hold of illegally acquired funds through theft, bribery and corruption, financial criminals move the cash from its source. This is where the criminal money is 'washed' and disguised by being placed into a legitimate financial system, such as in offshore accounts.

\section{Layering}

The second stage in the money laundering process is referred to as 'layering'. This is a complex web of transactions to move money into the financial system, usually via offshore techniques.

Once the funds have been placed into the financial system, the criminals make it difficult for authorities to detect laundering activity. They do this by obscuring 


\section{Beny Saputra \\ Modelling Australian Transaction Reports and Analysis Centre (AUSTRAC) for Indonesia in Order to Combat Financial Crime}

the audit trail through the strategic layering of financial transactions and fraudulent bookkeeping.

Layering is a significantly intricate element of the money laundering process. Its purpose is to create multiple financial transactions to conceal the original source and ownership of the illegal funds.

\section{Integration}

The third of the stages of money laundering is 'integration'. The 'dirty' money is now absorbed into the economy, for instance via real estate. Once the 'dirty' money has been placed and layered, the funds will be integrated back into the legitimate financial system as 'legal' tender. Integration is done very carefully from legitimate sources to create a plausible explanation for where the money has come from.

This money is then reunited with the criminal with what appears to be a legitimate source. At this stage, it is very difficult to distinguish between legal and illegal wealth. The launderer can use the money without getting caught. It is extremely challenging to catch the criminal if there is no documentation to use as evidence from the previous stages.

It is important to note that, in reality, there is often an overlap in these three stages of money laundering. As in some cases of financial crimes, there is no requirement for the illegal funds to even be 'placed'.

\section{Examples of The Money Laundering Stages}

The money laundering process is extremely complex and can involve multiple individuals involved in organised crime. Now that you understand the meaning of money laundering, let's discuss the three money laundering stages in more detail.

How is the Placement Money Laundering Stage Achieved?

There are several ways the 'dirty' money can be entered into the financial system. The six most common examples of crime associated to the placement stage in the laundering money process are: 
NEGREI : Academic Journal of Law and Govenance,

Volume 1, Number 2, 2021

a. Blending of funds:

This process is whereby businesses blend illegal funds with legitimate takings. This is typically done through cash businesses such as tanning salons, car washes, casinos, and strip clubs, as they have little or no variable costs. Historically, this was done through laundrettes, hence the term 'money laundering'.

b. Invoice fraud:

Invoice fraud is the most common technique used for transferring dirty money. Primary techniques include: over-invoicing or under-invoicing, falsely described goods/services, and phantom shipping (where no items have been shipped and the fraudulent documentation was produced to justify the payment abroad).

c. Through 'smurfing'

'Smurfing' is the act of breaking a large sum into smaller and less-suspicious transactions below the reporting threshold. The illegal funds are often deposited into one or multiple bank accounts by either multiple people (known as smurfs) or by a single person over a long period.

\section{d. Offshore Accounts}

Laundered money is often hidden through offshore accounts as this process easily hides the identity of the real beneficial owners and is a way to evade paying tax to HMRC. Offshore accounts are bank accounts opened in a country outside of where an individual resides.

e. Carrying Small Sums of Cash Abroad

Money can be laundered by carrying small sums of cash abroad below the customs declaration threshold. Then this cash is paid into foreign bank accounts before sending it back home.

\section{f. Through Aborted Transactions}

The money is transferred to a lawyer or accountant to hold until a proposed transaction is completed. The transaction is then cancelled, and the funds are repaid to the criminal from an unassailable source.

Layering of the this staged achieved with:

1. The second and most complex stage of layering often involves the following tactics: 


\section{Beny Saputra}

Modelling Australian Transaction Reports and Analysis Centre (AUSTRAC) for Indonesia in Order to Combat Financial Crime

2. Moving money electronically between different countries using loopholes in legislation.

3. Converting money into financial instruments such as stocks.

Investing in real estate or 'shell' companies with a functional front. the layering stage is all about turning the dirty money into large sums of clean and untraceable funds.

Integration of this staged achieved with:

Often 'dirty' money is 'cleaned' and integrated into financial systems through:

1. Investments into the property market, high-end cars, artwork, jewellery or other highly-priced commodities.

2. False invoices with the over-evaluation of the value of goods imported or exported into a country.

The launderer can now enjoy their illegal wealth, believing that the laundered money won't be traced back to them.

\section{Impact of the money laundry}

\section{The Economic Cost of Money Laundering}

Money laundering harms financial sector institutions critical to economic growth. Money laundering promotes crime and corruption that slows economic growth and decreases productivity in the real sector economy. Money laundering is a problem both in the world's major financial markets both in emerging markets. As emerging markets develop their economies and financial sectors, they are increasingly becoming suitable targets for money laundering activities. In addition to creating unpredictable money demand changes, money laundering causes large fluctuations in international capital flows and exchange rates. The adverse effects of money laundering on the economy can be discussed in many subjects, such as money demand, growth rates, income distribution, tax revenues, financial institutions.

\section{The Social Cost of Money Laundering}

There are not only economic but also significant social costs and risks associated with money laundering. Money laundering allows criminals such as drug traffickers to expand their operations. This increases the government's cost due 
NEGREI : Academic Journal of Law and Govenance,

Volume 1, Number 2, 2021

to the increased law enforcement and the need for healthcare spending to combat the serious consequences. Money laundering briefly transfers economic power from the government, citizens, and the market to criminals. Furthermore, the magnitude of the economic power accruing to criminals without money laundering has a degenerative effect on all society elements. Money laundering can lead to a virtual takeover of a legitimate government.

Overall, money laundering presents a complex and dynamic challenge to the world community. If governments want to reduce the ability of criminals to launder their income and conduct criminal activities, they must certainly cope with the global nature of money laundering, global standards, and international cooperation. Besides, Governments reduce public spending that will spend more money on AML regulations and law enforcement through a backlash. The result is that the normal citizen is badly affected.

\section{The Adverse Money Laundering Implications for Developing Countries}

Countries Money laundering and financing of terrorism can occur in any country, but the value of the damage it causes may vary from country to country. Especially for developing countries, money laundering has significant economic and social consequences because markets here tend to be small and more susceptible to disruption from criminal or terrorist influences. Of course, money laundering and financing of terrorism also have significant economic and social consequences for countries with fragile financial systems. These countries are also susceptible to cuts from such effects. Ultimately, the economy, society, and security of countries used as money laundering or terrorist financing platforms are at stake. We will examine the effects of money laundering on developed countries in the rest of the article.

\section{International Consequences and Foreign Investment}

Any developing country with a reputation as a haven for money laundering or terrorist financing could have significant negative consequences for development. Foreign financial institutions can limit their transactions with institutions from money laundering heavens, stop their investments, make transactions more expensive, and be subject to extra scrutiny. Even legitimate businesses and organizations living in money laundering heavens can suffer from reduced access to world markets or higher costs due to extra scrutiny of their ownership, organization, and control systems. As a result, with the loose 
Beny Saputra

Modelling Australian Transaction Reports and Analysis Centre (AUSTRAC) for Indonesia in Order to Combat Financial Crime

implementation of AML / CFT, any known country is less likely to receive foreign private investment. Moreover, for developing countries, eligibility for foreign state aid is likely to be severely restricted.

\section{Increased Crime and Corruption}

Seeing a country as a money-laundering haven is likely to attract criminals and encourage corruption. Several factors lead to increased crime and corruption, for example, a weak AML / CFT regime, too little, weak or selective enforcement of AML / CFT provisions, ineffective penalties including hard seizure provisions, and a limited number of precursor offenses for money laundering. If money laundering is widespread in a country, crimes such as corruption occur more.

Criminals also increase bribery by the country's major institutions to make their money laundering efforts successful. Although many institutions can be used in bribery, the employees and management of financial institutions, lawyers and accountants, legislatures, supervisory authorities, police officials, prosecutors, and courts come at the beginning of them. Timely and effective practices in countries can significantly reduce this criminal activity's profitable profits and deter crimes.

\section{Analyze of Anti-Money Laundering (AML), Terrorist Financing, and Trade Sanctions Law in Indonesia}

The main legislation covering money laundering is the Money Laundering Law. In addition, Law No 3 of 2011 on Fund Transfer (Fund Transfer Law) also relates to the Money Laundering Law.

The Bank of Indonesia Regulation No 14/27/PBI/2012 on implementation of Anti-Money Laundering and Combating the Financing of Terrorism Programs for Commercial Banks (BI Anti-Money Laundering Regulation) also regulates aspects of money laundering.

Bank of Indonesia also issued Regulation No 19/10/PBI/2017 concerning Implementation of Anti-Money Laundering and Prevention of Terrorism Financing for Non-Bank Payment System Service Provider and Non-Bank Currency Exchange Service Procedure (BI Terrorist Financing Regulation). 
NEGREI : Academic Journal of Law and Govenance,

Volume 1, Number 2, 2021

In relation to the financial sector, the OJK has issued OJK Regulation No 23/POJK.01/2019 on Amendment of OJK Regulation No 12/POJK/2017 on the Implementation of Anti-Money Laundering Program and Prevention of Terrorist Financing at the Financial Sector (OJK Anti-Money Laundering and Terrorist Financing Regulation).

\section{Terrorist financing}

Terrorist financing is regulated by:

1. Law No 9 of 2013 on the Prevention and eradication of Terrorism Financing Crimes (Terrorism Financing Law).

2. Law No 5 of 2018 on Amendment of Law No 15 of 2003 on Stipulation of Government Regulation in lieu of Law No 1 of 2002 on Elimination of Criminal Acts of Terrorism (Terrorism Law).

3. BI Anti-Money Laundering Regulation.

4. BI Terrorist Financing Regulation.

5. OJK Anti-Money Laundering and Terrorist Financing Regulation.

\section{Offences}

Article 2 of the Money Laundering Law sets out 26 exhaustive "criminal actions" which include corruption, bribery, smuggling psychotropic, narcotics or individuals, criminal actions in relation to banking, capital markets, insurance, taxation, customs or excise, human trafficking, trading in illegal firearms, terrorism, kidnapping, burglary, embezzlement, fraud, money counterfeiting, gambling, prostitution, criminal actions in relation to forestry, the environment, marine environment and fisheries, or other criminal actions that carry a sanction of imprisonment of at least four years.

Articles 3, 4 and 5 of the Money Laundering Law deals with crimes by individuals, and Articles 6 and 7 deals with crimes by corporations.

Article 3 offences. Under Article 3 of the Money Laundering Law, anyone who places, transfers, forwards, spends, pays, grants, deposits, takes abroad or changes currency, securities or other deeds towards assets that are recognised or reasonably alleged to be the result of criminal action with the purpose of hiding or disguising the assets' origin will commit an offence.

Article 4 offences. Under Article 4, anyone who hides or disguises the origin, source, location, purpose or transfer of right or ownership of assets that are 


\section{Beny Saputra \\ Modelling Australian Transaction Reports and Analysis Centre (AUSTRAC) for Indonesia in Order to Combat Financial Crime}

known by him/her, or which are reasonably alleged, to be the result of criminal action, will commit an offence.

Article 5 offences. Under Article 5, anyone who accepts or controls placement, transfer, payment, grant, deposit, exchange or utilises assets that is known, or should be known to him, to have resulted from a criminal action, has committed an offence.

Article 6 offences. If a corporation is responsible for a crime stipulated under Article 3, 4 and 5, the sentence will be subjected towards the corporation and/or the persons controlling the corporation.

Article 7 offences. If a corporation commits money laundering, the sentence may be applied to both the corporation and/or corporation control personnel, under Article 6 of the Money Laundering Law.

\section{Terrorist financing}

Article 4, Terrorism Financing Law. Any person who intentionally provides or collects, gives, or lends funds directly or indirectly with the objective that they be used partly or wholly for criminal acts of terrorism will commit an offence.

Article 5, Terrorism Financing Law. Any person who reaches an agreement, attempts or assists in the conduct of terrorism financing will be subject to the same sanctions as persons in violation of Article 4 of the Terrorism Financing Law.

Article 6, Terrorism Financing Law. Any person who intentionally plans, organises, or instigates other persons to conduct terrorism financing will commit an offence.

In the event that offences under Article 4, 5, and 6 of the Terrorism Financing Law were to be conducted by a corporation, the sanction will be directed towards the corporation and/or the persons who control the corporation.

\section{Financial/trade sanctions}

Indonesia has enacted Law No 7 of 2014 on Trade, prohibiting trade of certain goods. Domestically, there are goods that cannot be traded by business owners for reasons of national security and sovereignty. Internationally there are also restrictions on exports of certain goods. The specific goods are listed in the 
NEGREI : Academic Journal of Law and Govenance,

Volume 1, Number 2, 2021

Presidential Regulation, Government Regulation, and Ministry Regulations. Recently, in light of the 2019 novel coronavirus disease (COVID-19), Indonesia has temporarily banned imports of livestock from and through China by virtue of Minister of Trade Regulation Number 10 of 2020.

\section{Authorities and Prosecution Anti-Money laundry In Indonesia}

Police investigators have the authority to investigate criminal offences related to money laundering.

In addition, the Financial Transaction Report and Analysis Centre (PPATK) (that is, an independent institution tasked with collecting, analysing, and evaluating suspicious transactions) can also assist the public prosecutors in money laundering investigations.

Furthermore, any crimes relating to the financial sector can also be investigated by OJK pursuant to OJK Regulation No 22/POJK.01/2015 on Criminal Investigations in the Financial Sector.

\section{Prosecution powers}

Under Article 13 of the Criminal Procedural Code, the public prosecutor has the power to conduct prosecutions. This includes the authority to:

- Accept and examine the case dossier submitted by the investigator. If the public prosecutor deems the dossier to be incomplete, it can return it to the investigator to be completed.

- Conduct pre-prosecutions and prosecutions before the court of law.

- Execute the rulings of the court.

In addition, Article 69 of the Money Laundering Law provides that in establishing a money laundering case, the prosecutor does not need to prove the existence of the crime that preceded the act of money laundering.

\section{Powers of interview}

Powers of interview are usually conferred on the investigator under Article 7(1) of the Criminal Procedural Code and Chapter VIII of Law No 8 of 2010. However, under Article 14(i) of the Criminal Procedural Code, the prosecutor can also conduct interviews. Such powers include questioning suspects and witnesses. 
Beny Saputra

Modelling Australian Transaction Reports and Analysis Centre (AUSTRAC) for Indonesia in Order to Combat Financial Crime

\section{Powers of search/to compel disclosure}

Powers of search/to compel disclosure are conferred on an investigating officer under Article 7(1) of the Criminal Procedural Code and Law No 8 of 2010.

\section{Powers to obtain evidence}

Other than evidence recognised under the Criminal Procedural Code, the Money Laundering Law also provides that information spoken, sent, or received electronically can be used as evidence. Powers to obtain evidence are conferred on an investigating officer under Article 7(1) of the Criminal Procedural Code, and this power is only to be exercised in the territory of Indonesia. However, Law No 8 of 2010 stipulates that investigating civil servants, prosecutors and judges also have the right to obtain evidence. Moreover, Article 72 of the Money Laundering Law provides that for the interest of the investigation, the investigator, prosecutor, and judge have the authority to request that the complainant must submit a written testimony relating to its assets from a suspect.

\section{Power of arrest}

Powers of arrest are conferred on an investigating police officer (Article 7(1), Criminal Procedural Code), the prosecutor in charge of the investigation (Article 14, Criminal Procedural Code) and also the judge.

Generally, for crimes committed by persons, money bail or personal bail can be requested by a suspect or defendant for postponement of detention (Article 31, Criminal Procedural Code). However, for corporations, the laws are silent.

\section{Court orders or injunctions}

In addition to the orders and injunctions available to the courts under the Criminal Procedural Code, the court can also order a seizure of assets of a convicted person who became deceased prior to the final judgment. Moreover, Articles 70(1) and 71(1) of the Money Laundering Law also provide that the authorities (the investigator, prosecutor, judge) have the power to:

- Cancel or suspend any transaction that is suspected of being money laundering.

- Block any asset/wealth that is suspected to be the result of money laundering. 
NEGREI : Academic Journal of Law and Govenance,

Volume 1, Number 2, 2021

- Summon any whistleblower to provide details of the suspects reported by the whistleblower.

Furthermore, Article 22 of the Terrorism Financing Law empowers the relevant authority to block funds that are suspected of being directly or indirectly used for terrorist acts. The authority also has the power to summon financial service providers to obtain details of the suspected funds.

For the criminal acts (money laundering and terrorist financing), the public prosecutor makes the decision to charge in accordance with the Criminal Procedural Code.

\section{Protection}

There are no specific protections available for suspects of money laundering, other than what is generally provided, such as clemency and amnesty.

\section{Conviction and sanction}

\section{Money laundering}

Right to bail.

Penalties. The penalties for money laundering are as follows.

1. For Article 3 money laundering offences: imprisonment of up to 20 years and a fine of up to IDR10 billion (individuals only).

2. For Article 4 money laundering offences: imprisonment of up to 20 years and a fine of up to IDR500 billion (individuals only).

3. For Article 7 money laundering offences: fine of up to IDR100 billion (corporations and individuals).

\section{Terrorist financing}

Right to bail.

Penalties. The maximum criminal sanctions for an individual for participating in terrorist financing are fines of up to IDR1 billion and imprisonment of up to 15 years.

Where applied to a corporation, a fine up to a maximum of IDR100 billion may be imposed (Article 4, Terrorism Financing Law). 


\section{Beny Saputra}

Modelling Australian Transaction Reports and Analysis Centre (AUSTRAC) for Indonesia in Order to Combat Financial Crime

Moreover, if a corporation is involved in any act of terrorism financing, it will be subject to a fine of up to IDR100 billion, its licence to operate could be revoked and it will be declared a banned corporation (Article 8(4) and 8(5)), Terrorism Financing Law). Furthermore, commercial banks must implement anti-money laundering and anti-terrorist financing programmes (Article 2, BI Anti-Money Laundering Regulation). Banks that do not implement such programmes may be subject to:

1. Written notices.

2. Downgrading of the bank's soundness rating.

3. A cease-and-desist order on specified business activities.

4. The termination of bank management and subsequently designation and appointment of temporary replacements until the general meeting of shareholders or until a co-operative member meeting appoints permanent replacements with the approval of the Bank of Indonesia.

5. The inclusion of the members of board of directors (board) and board of commissioners, bank employees and shareholders on the banking blacklist.

In addition, similar rules apply to non-bank payment system service providers (Article 2, BI Terrorist Financing Regulation). Violations of the provisions of the BI Terrorist Financing Regulation are punishable with administrative sanctions, either to the organisers or to members of the board of directors, members of the board of commissioners, shareholders and/or the executive of such service providers.

\section{Financial/trade sanctions}

Right to bail.

Penalties. Exporters and importers that violate prohibitions on trade, such as trading prohibited goods to foreign countries, will be subjected to imprisonment of up to five years and/or a fine of up to IDR5 billion.

\section{Safeguard}

In addition to the general safeguards under the Criminal Procedural Code (pretrial, and the mechanism of appeal, cassation, and reconsideration of case as regulated under the Criminal Procedural Code), for money laundering cases a 
NEGREI : Academic Journal of Law and Govenance,

Volume 1, Number 2, 2021

defendant can request to go through a general appeal procedure under Article 80 of the Money Laundering Law.

From all the law descripted above about money laundry, we can see that there is no particular mention about Anti-Money Laundry (AML) in financial technology, the articles and laws above only regulates about traditional financial system and conservative money laundry system. Eventhough the financial technology massively growing in Indonesia there is no such laws regulate it, it potentially become rechtvaccum or no law avalaible to manage such issue. Clearly, there is law, legal and judicial systems issue in this sector

This regulation is inefficient and still not effective againts Money Laundry. Because, according to The Financial Reports and analysis centre (PPATK) public report May 2020, there are 33751 money laundry attemp during 2019-Q1 2020. The number is increase more than 10000 attempt particulary after the booming of financial technology, digital banking and through cryptocurrency and also as Financial Service Authority (OJK) report per may 2020, 338 illegal financial technology closed mostly the reason due to money laundry attemption. the increasing of the cases number its the fact the current regulation is not effective, instead of decreasing, the case numbe increase year to year after the cental bank policies and OJK regulations released.

In order to manage to catch up with the development of the financial technology in Indonesia, modern and practical law in term of Anti-Money Laundry urgently needed in. With the put the data collection and analysis requirements mandated by AML regulations within their jurisdiction, firms should integrate suitable compliance software within their solution, including a range of smart technology tools. Automated AML technology adds speed, efficiency, and accuracy benefits to the compliance process, and reduces the potential for costly human error. Smart technology also allows firms to adapt to emergent criminal methodologies and to changes in the regulatory landscape as new AML legislation is introduced. One of the most advance law system for againts money launderer its a AUSTRAC in Australia, which can prevent money laundery in financial technology. 


\section{Beny Saputra \\ Modelling Australian Transaction Reports and Analysis Centre (AUSTRAC) for Indonesia in Order to Combat Financial Crime}

\section{Australian Transaction Reports and Analysis Centre} (AUSTRAC)

AUSTRAC (Australian Transaction Reports and Analysis Centre) is the Australian Government agency responsible for detecting, deterring and disrupting criminal abuse of the financial system to protect the community from serious and organised crime. With the vision A financial system free from criminal abuse and with purpose To build resilience in the financial system and use financial intelligence and regulation to disrupt money laundering, terrorism financing and other serious crime.

Through strong regulation, and enhanced intelligence capabilities, AUSTRAC collects and analyses financial reports and information to generate financial intelligence. This vital information about potential criminals and criminal activity contributes to our national security and law enforcement investigations

For more than 30 years, AUSTRAC has been evolving to address the challenges in a financial system that is rapidly changing and targeted by criminals in complex ways. Today, AUSTRAC finds itself working in a disrupted financial landscape, with new and emerging technologies changing the way financial services are delivered, in an increasingly globalised economy. These disruptions have created significant changes in the sector and AUSTRAC has adapted to these shifts in how it regulates businesses to disrupt financial crime to protect the community.

As criminals become more sophisticated and develop new ways to exploit vulnerabilities in the Australian financial system, we will continue to evolve and deepen how we work with our reporting population and partners. This is enabled by our highly collaborative approach and specialist work force.

\section{Technology Used by AUSTRAC}

As Australia's financial intelligence unit (FIU), AUSTRAC collects information from the thousands of entities regulate. AUSTRAC financial intelligence analysts use that information to identify financial transactions linked to crimes including money laundering, terrorism financing, organised crime, child exploitation and tax evasion. 
NEGREI : Academic Journal of Law and Govenance,

Volume 1, Number 2, 2021

AUSTRAC share the findings with a wide range of domestic and international partner agencies in law enforcement and security. AUSTRAC also participate in a number of national and state task forces, providing specialist financial intelligence to national security and transnational serious and organised crime efforts.

AUSTRAC also act as Australia's AML/CTF regulator. In this capacity AUSTRAC oversee the compliance of more than 15,000 reporting entities with their AML/CTF obligations, including reporting financial transactions and suspicious activity to AUSTRAC.

AUSTRAC closely analyse the information in these reports using sophisticated modelling and predictive analysis tools in combination with other data sources to identify potential criminal activity or risks to national security. then share this intelligence with their partners to support law enforcement and national security operations.

\section{Intelligence sharing}

Intelligence partnerships, both public and private, are fundamental for AUSTRAC. By sharing financial intelligence, AUSTRAC play a vital role in helping law enforcement and security agencies to detect and disrupt criminal activity in Australia and around the world.

\section{Government partners}

AUSTRAC financial intelligence makes a significant contribution to the national intelligence picture and supports investigations by the government partners at federal and state level.

AUSTRAC actively share intelligence reports with the government partners to help in their work to detect and disrupt criminal activity. the partners also have direct access to their data holdings and can search information directly to support their national security and law enforcement work. More than 5,000 users across 39 different partner agencies accessed our data holdings in 2017-18.

AUSTRAC also share data with government agencies that don't have direct access to data holdings but who may need specific information to help with their investigations - for example, the Australian Sports and Anti-Doping Association (ASADA). 
Beny Saputra

Modelling Australian Transaction Reports and Analysis Centre (AUSTRAC) for Indonesia in Order to Combat Financial Crime

\section{Law enforcement task forces}

AUSTRAC is a member of a number of national and state law enforcement task forces. We provide specialist financial intelligence to help combat serious criminal activity, including money laundering, terrorism financing, organised crime and tax evasion.

\section{Data matching with AUSTRAC domestic partner agencies}

Matching data with data held by selected partner agencies can help identify individuals under investigation. For example, AUSTRAC matches data with data from the Australian Taxation Office (ATO) to identify individuals who may not be declaring income or paying their tax. AUSTRAC also match their data with data from the Department of Human Services to help combat benefit fraud and improve the integrity of the welfare system.

\section{International partners}

To combat money laundering and terrorism financing across borders, AUSTRAC also share financial intelligence with other AML/CTF FIUs and regulators around the world. AUSTRAC negotiate written agreements (exchange instruments) with each foreign jurisdiction or organisation. These agreements set out the framework for how they will exchange information with foreign jurisdictions or organisations.

\section{Regulation}

As Australia's AML/CTF regulator, AUSTRAC regulates more than 14,000 individuals, businesses and organisations.

AUSTRAC convinced they're complying with AUSTRAC obligations under the Anti-Money Laundering and Counter-Terrorism Financing Act 2006 (AML/CTF Act) and the Financial Transaction Reports Act 1988 (FTR Act). to protect them, and the financial sector, from criminal abuse.

Our reporting entities' obligations include reporting financial transactions and suspicious activity to AUSTRAC through, for example:

- suspicious matter reports (SMRs)

- threshold transaction reports (TTRs)

- international funds transfer instructions (IFTI) reports. 
NEGREI : Academic Journal of Law and Govenance,

Volume 1, Number 2, 2021

regulatory activities also include:

- identifying new and emerging risks

- identifying and collecting data to generate regulatory insights.

- using regulatory insights and financial intelligence to assess industry vulnerabilities and threats to Australia's financial sector

- collaborating with industry to improve risk management, help them comply, educate them on risks and compliance

- supporting national security and law enforcement operations

- taking a risk-based approach to interventions against non-compliant reporting entities

- taking enforcement action against reporting entities for serious and/or systemic breaches of the AML/CTF Act.

\section{AUSTRAC recent cases combating money laundering}

\section{Offender convicted of structuring funds to launder money: $\$ 1$ million recovered}

AUSTRAC was alerted to the activities of the offender by a bank, who submitted a Suspicious Matter Report (SMR). Subsequent investigation by AUSTRAC revealed that the offender was deliberately dividing large amounts of cash from his business into smaller amounts before depositing them, to avoid threshold reporting requirements. He structured cash deposits totalling more than AU $\$ 2.5$ million over a five-year period.

Further AUSTRAC information revealed:

1. Over five years, the offender made regular cash deposits into his personal credit card account. These amounts were just below the $\$ 10,000$ cash transaction reporting threshold.

2. In one three-month period, the offender deposited $\$ 125,000$ in cash into his personal credit card account in a series of $\$ 9,000$ deposits.

3. The offender exchanged $\$ 15,000$ in cash from $\$ 50$ notes to $\$ 100$ notes.

4. The offender deposited $\$ 250,000$ in cash and $\$ 450,000$ in cheques, on the same day, into his term deposit account. The cheques were drawn from personal and business accounts held by the offender with another bank. 
Beny Saputra

Modelling Australian Transaction Reports and Analysis Centre (AUSTRAC) for Indonesia in Order to Combat Financial Crime

He was charged with Commonwealth offences relating to structuring transactions and pleaded guilty to all. He was ordered to pay a penalty of over AU $\$ 1$ million.

\section{International drug importation scheme targeted, and trafficker convicted}

SMRs were received from several remittance service providers relating to one individual, which initiated an investigation by AUSTRAC. These SMRs showed:

1. A higher than normal volume and frequency of international funds transfer instructions (IFTIs).

2. All outgoing IFTIs were paid for in cash, in structured amounts below the $\$ 10,000$ cash reporting threshold.

3. The recording of multiple address details and telephone numbers.

4. Addresses slightly altered or completely different to previous transactions.

AUSTRAC commenced an investigation into these transactions, identifying the overseas beneficiary customers, along with other aliases and identities used by the suspect. AUSTRAC was then able to monitor these aliases and any financial transactions conducted by them. Data showed a correlation between the transfers of funds to Laos, Brazil and Nigeria and the importation of drugs. The suspect was charged and convicted of drug importation offences, and for dealing with the proceeds of crime.

\section{Online transactions led to convictions for child sex offences}

AUSTRAC contributed to an investigation into the use of pay-per-view child pornography websites and chatrooms based in the Philippines by Australian suspects.

AUSTRAC prepared financial intelligence assessments to support the investigation on various transactions conducted by two suspects. This investigation uncovered a number of international money transfers sent via remittance service providers to common beneficiaries in countries such as Thailand and the Philippines. These money transfers were frequent and for small amounts; approximately half were between $\$ 10$ and $\$ 100$, and the other were between $\$ 10$ and $\$ 1,000$. 
NEGREI : Academic Journal of Law and Govenance,

Volume 1, Number 2, 2021

The two suspects were successfully charged and convicted of child sex offences under Commonwealth and Victorian jurisdictions. They were sentenced to jail time with sex offender therapy.

\section{Australia and Colombia join forces to bring down international drug syndicate}

Australian and Colombian law enforcement agencies conducted a joint investigation into an international drug syndicate with links to Thailand, Ecuador, Italy, the USA, and France.

The syndicate were using couriers to smuggle drugs from Colombia and the USA into Australia. AUSTRAC became involved when they received an SMR from a currency exchange service regarding a customer who was travelling to Colombia, and insisted on exchanging Australian dollars for Euros in cash, rather than as a cash passport as suggested by the currency exchange service. The funds exchanged were also below the transaction reporting threshold.

AUSTRAC then analysed the financial activities of other suspects and prepared financial intelligence assessments. Analysis of international funds transfers showed that a number of Australian suspects were linked to the suspect based in Colombia. AUSTRAC also discovered information about an Australian suspect who exchanged AU \$11,000 for US dollars on the day she departed for the US. She returned to Australia and was discovered carrying $140 \mathrm{~g}$ of methamphetamine concealed on her person.

AUSTRAC shared financial intelligence with counterpart authorities in the United States, assisting authorities to confirm drug syndicate associations in the U.S.

\section{AUSTRAC Role Anti-Money Laundry Model for Indonesia}

AUSTRAC is Australia's anti-money laundering and counter-terrorism financing regulator and financial intelligence unit. It oversees the compliance of financial services providers and other related Australian businesses, who are required to notify it of suspicious matters and other significant transactions. Recent investigations show that AUSTRAC successfully collaborates with domestic and international partner agencies, providing financial intelligence which leads to the disruption of significant money laundering and organised crime operations. 
Beny Saputra

Modelling Australian Transaction Reports and Analysis Centre (AUSTRAC) for Indonesia in Order to Combat Financial Crime

Indonesian and Australian officials signed an agreement to target money laundering and the financing of terrorism. The agreement involves closer cooperation between Indonesia's Financial Transactions Report and Analysis Center (PPATK) and the Australian Transaction Reports and Analysis Center (Austrac). The PPATK-Austrac Partnership Program 2017 is a seven-year collaboration, which will see the Australian and Indonesian governments join forces in a new six-pronged approach to cut terrorists' financial lifelines. This will include the deployment of information technology specialists to strengthen the PPATK's report and analysis systems, and exchange programs to enable PPATK experts to learn first-hand from Austrac.

Indonesia must take the opportunity of the cooperation along with implementation of Indonesia-Australia Comprehensive Strategic Partnership (IA-CEPA 2020-2024) to learn and adopt technology used by AUSTRAC. Indonesia without any adjustable to the modern and practical law as used by AUSTRAC, wont able to solve the money laundry case in financial technology.

However, Australia's Department of Foreign Affairs and Trade has recently approved new funding for AUSTRAC's work in Indonesia. This recognises the value of AUSTRAC's international work in supporting Australia's national interests in Indonesia. This funding helps AUSTRAC deliver important capacity building, relationship building and national interest outcomes through the 'PPATK AUSTRAC Partnership Program' (PAPP) and through the new, 'Australia Indonesia Partnership for Justice' (AIPJ) program.

\section{Conclusion}

The applicable law in Indonesia for financial crime, particularly money laundering, terrorist financing, and trade sanctions, is out of date and needs to be updated to reflect current conditions. The rapid development of financial technology in Indonesia has not been accompanied by an advanced and modern legal system to regulate it. Despite this, no law currently governs anti-money laundering in financial technology (FinTech) and its potential repercussions (rechtvaccuum) in Indonesia's legal system. Indonesia can improve on the agreement reached with Australia under IA-CEPA 2020-2024 by adopting and transferring technology from the Australian Transaction Reports and Analysis Centre (AUSTRAC) for the prevention of money laundering in the country. 
NEGREI : Academic Journal of Law and Govenance,

Volume 1, Number 2, 2021

\section{Bibliography}

Business Forensic, the history of financial crime, Hague, Bruseel, Vol. 1 No 1 August 2021, Electronic journal, 2021

Economic Perspectives, The Fight against Money Laundering, US Department of State, Vol. 6. No 2, May 2001, Electronic Journal, 2001

Elementry, Railsbank, Stripe, Russi, Anti-Money Laundry in Indonesia: what you need to know, Vol 3 no 5, June 2021, Electronic Journal, 2021

Gibson, Nyiman, Miralis, AUSTRAC's Role in Combating Money laundring, online blog, 2021

Lal, B. Money Laundering: An Insight into the Dark World of Financial Frauds, Siddharth Publications, Delhi, India, 2003

Money Laundering Special Report Bureau of Justice Statistics, complied by M. Motivans, July 2003, NCJ 199574, 2003

Masciandaro, D. Money Laundering: The Economics of Regulation, European Journal of Law and Economics, 7, no. 3: 225-240. 2019

Masciandaro, D., and U. Filotti, Money Laundering Regulation and Bank Compliance Costs: What do your Customers Know? Economics and the Italian Experience, Journal of Money Laundering Control, Vol. 5, No. 2, pp. 133-145, 2021

Masciandaro, D. and A. Portolano, Inside the Black (list) Box: Money Laundering, Lax Financial Regulation, Non-cooperative Countries. A Law and Economics Approach. Paulo Baffi Center, Bocconi University and Bank of Italy, 2002

Reuter, P. and E. M. Truman, Chasing Dirty Money — The Fight against Money Laundering, Institute for International Economics, Washington DC, 2021

Thomson Reuter Practical Law, Financial Crime In Indonesia, Overview, Vol. 2, No 3, May 2021, electronic Journal, 2021

United Nations Office on Drugs and Crime Money Laundering web: http://www.unodc.org/unodc/en/money laundering.html , 2005

AUSTRAC web https://www.austrac.gov.au/ , 2021

ST Paulus Chamber, Stages of money laundering explained, web https://www.stpaulschambers.com/stages-of-money-launderingexplained/. 2021 